\section{JURNAL PARSPARTIII Junnal Kä|ian Sosidoci dan Pendidikkn}

Jurnal Perspektif: Jurnal Kajian Sosiologi dan Pendidikan Vol. 3 No. 1 Tahun 2020

http://perspektif.ppj.unp.ac.id

Email: perspektif@ppj.unp.ac.id

ISSN: 2622-1748 (Online), 2684-902X (Print)

DOI: http://dx.doi.org/10.24036/perspektif.v3i1.199

\title{
Hubungan Kelompok Teman Sebaya terhadap Gaya Hidup Hedonisme pada Mahasiswa
}

\author{
Ike Nur Jannah ${ }^{1}$, Ike Sylvia ${ }^{2}$ \\ ${ }^{1,2}$ Universitas Negeri Padang \\ Email: ikenjh14@gmail.com, ikesylvia@fis.unp.ac.id
}

\begin{abstract}
Abstrak
Penelitian ini dilakukan dengan tujuan untuk mengetahui hubungan kelompok teman sebaya terhadap gaya hidup hedonisme mahasiswa. Jenis penelitian ini adalah ex post facto. Subjek dalam penelitian ini adalah mahasiswa S1 Fakultas Ilmu Sosial Universitas Negeri Padang tahun masuk 2016, 2017, 2018, 2019, yang terdaftar pada semester Juli sampai Desember 2019. Jumlah sampel pada penelitian ini sebanyak 98 mahasiswa. Penelitian ini menggunakan dua jenis variabel yaitu: 1) variabel bebas: kelompok teman sebaya $(\mathrm{X}), 2)$ variabel terikat: gaya hidup hedonisme mahasiswa (Y). Pengumpulan data untuk variabel kelompok teman sebaya dan gaya hidup hedonisme mahasiswa menggunakan metode angket dengan skala Likert. Keabsahan data didapatkan dengan cara melakukan uji validitas dan reliabilitas. Hasil uji hipotesis dengan rumus korelasi product moment diperoleh nilai $\mathrm{r}$ hitung $0,140<$ nilai $\mathrm{r}$ tabel 0,198 . Hasil uji korelasi indikator kerjasama diketahui $\mathrm{r}$ hitung $<\mathrm{r}$ tabel yaitu 0,0499<0,1986 tidak ada korelasi, persaingan yaitu 0,0116<0,1986 tidak ada korelasi, pertentangan yaitu $0,4207>0,1986$ ada korelasi, penerimaan yaitu $-0,1043<0,1986$ tidak ada korelasi, penyesuaian $0,0041<0,1986$ tidak ada korelasi, dan perpaduan $0,479>0,1986$ ada korelasi, hal ini berarti tidak ada hubungan kelompok teman sebaya terhadap gaya hidup hedonisme pada mahasiswa.

Kata kunci: Gaya hidup hedonism, Kelompok teman sebaya
\end{abstract}

\begin{abstract}
This research was conducted with the aim of finding out the relationship of peer groups to the lifestyle of student hedonism. This type of research is ex post facto. Subjects in this study were undergraduate students of the Faculty of Social Sciences, Padang State University in 2016, 2017, 2018, 2019, who were registered in the semester from July to December 2019. The number of samples in this study were 98 students. This study uses two types of variables, namely: 1) independent variables: peer group $(X), 2)$ dependent variables: student hedonism lifestyle $(Y)$. Data collection for peer group variables and lifestyle of student hedonism used a questionnaire method with a Likert scale. The validity of the data is obtained by conducting a validity and reliability test. Hypothesis test results with the product moment correlation formula obtained $r$ count value of 0.140 <value of $r$ table 0.198 . The correlation test results of cooperation indicators are known $r$ count $<r$ table that is 0.0499 $<0.1986$ there is no correlation, competition is $0.0116<0.1986$ there is no correlation, contradiction is $0.4207>0.1986$ there is a correlation, acceptance is $-0.1043<0.1986$ there is no correlation, adjustment $0.0041<0.1986$ there is no correlation, and the combination of 0.479>0.1986 there is a correlation, this means that there is no relationship of peer groups to the lifestyle of students hedonism.
\end{abstract}

Keywords: Hedonism Lifestyle, Peer Group

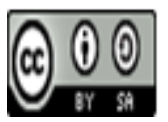

Received: January 14, 2019

Revised: January 28, 2020

Available Online: January 29, 2020 


\section{Pendahuluan}

Perubahan merupakan suatu fenomena yang pasti akan terjadi dalam kehidupan, baik itu perubahan-perubahan besar maupun perubahan kecil. Kingsley Davis dalam (Nanang, 2011) menjelaskan perubahan sosial sebagai perubahan-perubahan yang terjadi dalam struktur dan fungsi masyarakat. Menurut Harper perubahan sosial didefinisikan sebagai pergantian (perubahan) yang signifikan mengenai struktur sosial dalam kurun waktu tertentu. Terdapat beberapa tipe perubahan struktur sosial yaitu: 1) perubahan dalam personal yang berhubungan dengan perubahan-perubahan peran dan individu-individu baru dalam sejarah kehidupan manusia yang berkaitan dengan keberadaan struktur, 2) perubahan dalam cara bagian-bagian struktur sosial berhubungan, 3) perubahan dalam fungsi struktur yang berkaitan dengan apa dan bagaimana masyarakat tersebut melakukannya, 4) perubahan dalam hubungan struktur yang berbeda, 5) munculnya struktur baru yang merupakan peristiwa munculnya struktur baru untuk menggantikan struktur sebelumnya. Perubahan struktur sosial dapat berpengaruh terhadap kehidupan suatu masyarakat tergantung bagaimana masyarakat menerima perubahan tersebut.

Menurut Himes dan Moore (Nanang, 2011) perubahan sosial memiliki tiga dimensi yaitu dimensi struktural, kultural, dan interaksional. Dimensi struktural, perubahan yang terjadi pada dimensi ini dalam bentuk struktur masyarakat, menyangkut perubahan dalam lembaga sosial. Dimensi kultural mengacu pada perubahan kebudayaan yang terjadi dalam masyarakat. Dimensi interaksional mengacu pada adanya hubungan sosial dalam mayarakat. Dimensi interaksional meliputi perubahan dalam frekuensi, perubahan dalam jarak sosial, perubahan perantara, perubahan aturan atau pola-pola, perubahan dalam bentuk interaksi. Perubahan struktur pada dimensi interaksional sangat mempermudah interaksi antar individu. Pada masa lalu segala bentuk interaksi harus dilakukan secara tatap muka dan membutuhkan orang lain untuk menyampaikan informasi, namun seiring perkembangan teknologi dan informasi, interaksi antar individu dapat dilakukan secara langsung meskipun tidak bertatap muka, dan ketika dua individu tersebut berjarak jauh. Perubahan struktur tersebut juga akan mempengaruhi pola interaksi individu didalam suatu kelompok. Perkembangan teknologi informasi yang sangat pesat dan data tentang layanan bisa dimaknai secara positif, dimana masyarakat Indonesia sudah memiliki tingkat melek teknologi informasi yang baik (Fernandes, Putra, \& Muspita, 2013)

Menurut Sachri dalam (Sa'adah, 2016) mendefinisikan gaya hidup atau life style merupakan segala hal atau sesuatu yang memiliki karakteristik, kekhususan, dan tata cara yang ada dalam kehidupan seseorang maupun masyarakat tertentu. Gaya hidup merupakan rangkaian kegiatan yang dilakukan oleh individu maupun kelompok, beberapa individu atau kelompok memiliki gaya hidup yang hanya mencari kesenangan saja dengan melakukan kegiatan dan menghabiskan waktunya diluar rumah serta mementingkan uang di atas segalanya. Gaya hidup tersebut merupakan gaya hidup hedonisme, Suseno dalam (Saputri \& Rachmatan, 2009) mendefinisikan hedonisme yang berasal dari bahasa Yunani yaitu hedone yang berarti nikmat kegembiraan. Kebahagiaan dan kenikmatan materi dijadikan sebagai tujuan utama kehidupan sehingga rela melakukan segala cara agar dapat mencapai tujuan tersebut. Amstrong dalam (Sa'adah, 2016) menjelaskan bahwa gaya hidup hedonisme merupakan suatu pola hidup dimana aktivitas yang dilakukan hanya untuk mencari dan mendapatkan kesenangan hidup, aktivitas tersebut seperti menghabiskan lebih banyak waktu berada diluar rumah, lebih banyak bermain, senang berada di keramaian dan menjadi pusat perhatian, merasa senang untuk membeli barang mewah dan mahal.

Gaya hidup hedonisme memiliki ciri-ciri menurut Susianto (1993) dalam (Rianton, n.d.) yaitu melakukan aktivitas untuk mencapai dan mendapatkan kesenangan hidup, 
menghabiskan lebih banyak waktu berada diluar rumah, memilih dalam berteman meskipun merasa mudah berteman, senang apabila menjadi pusat perhatian, waktu luang digunakan hanya untuk bermain, anggota kelompok kebanyakan merupakan orang yang berada. Menurut Well dan Tigert dalam (Nur Ambadra, 2018) aspek-aspek gaya hidup hedonisme yaitu minat, aktivitas, dan opini. Minat merupakan segala sesuatu yang menarik dari suatu lingkungan individu atau kelompok, minat dapat muncul baik itu terhadap suatu kejadian, objek, atau topic yang berhubungan dengan kesenangan hidup seperti fashion, makanan, barang-barang yang mahal dan mewah, tempat untuk berkumpul, dan merasa selalu ingin menjadi pusat perhatian. Aktivitas merupakan cara individu atau kelompok dalam menggunakan waktunya dalam bentuk tindakan nyata yang dapat dilihat, misalnya pergi ke tempat hiburan seperti café, bioskop, pergi ke tempat perbelanjaan seperti mall, pasar atau swalayan. Opini merupakan pendapat seseorang maupun kelompok yang disampaikan saat merespon situasi ketika timbul pernyataan-pernyataan atau tentang isu-isu sosial dan produkproduk yang berkaitan dengan hidup.

Menurut Kotler (1997) dalam (Erliana, 2018) ada dua faktor yang dapat mempengaruhi gaya hidup seseorang yaitu faktor eksternal dan faktor internal. Faktor eksternal meliputi kelas sosial, kelompok referensi, keluarga dan kebudayaan. Faktor kedua yaitu faktor internal yang meliputi sikap, pengalaman, dan pengamatan konsep diri, kepribadian dan motif. Kelompok referensi menjadi salah satu faktor yang mempengaruhi gaya hidup hedonisme, hal tersebut didukung oleh penelitian yang telah dilakukan oleh Dhea Laksmi Rahmalisa (2015) dalam hasil penelitian menunjukkan terdapat hubungan yang positif antara konformitas terhadap teman sebaya dengan gaya hidup hedonisme pada mahasiswa dengan $\mathrm{p}=0,000(\mathrm{p}<0,01)$.

Menurut Brown (Sihotang, 2009) kelompok teman sebaya merupakan suatu bentuk interaksi seseorang baik itu anak atau remaja dengan teman sepermainan yang memiliki tingkat usia, minat, dan tujuan yang sama. Terdapat beberapa indikator kelompok teman sebaya menurut Park Burges dalam (Mardiani Amelia, 2007) yaitu kerjasama, persaingan, pertentangan, penerimaan, penyesuaian, dan perpaduan. Kelompok teman sebaya terdiri dari beberapa orang yang memiliki kepribadian dan latar belakang yang berbeda dan dapat memberikan pengaruh yang baik maupun buruk terhadap kelompok teman sebayanya. Pengaruh baiknya dapat dilihat seperti apabila memilih kelompok teman sebaya yang didalam terdapat seseorang atau lebih yang gaya hidup hedonis maka hal tersebut akan berpengaruh pula terhadap teman lain yang terhubung dalam kelompok tersebut. Dalam keadaan seperti ini, dapat dikatakan bahwa motivasi untuk menuruti ajakan dan aturan kelompok cukup tinggi, karena mengganggap aturan kelompok adalah paling benar serta ditandai dengan berbagai usaha yang dilakukan agar diterima dan diakui keberandaannya dalam kelompok (Irfan \& Sylvia, 2012)

Berdasarkan Teori kebutuhan McClelland (McClelland's Theory of needs) dikembangkan oleh David McClelland dan rekan-rekannya. Teori ini berfokus pada tiga kebutuhan yaitu kebutuhan pencapaian (need for achievement), kebutuhan kekuasaan (need for power), dan kebutuhan hubungan (need for affiliaton) (El Adawiyah, 2019). Teori McClelland (Nanang, 2011) yang dikenal dengann teori n-Ach (neeed for achievement) menjelaskan kebutuhan untuk berprestasi dalam mendukung kemajuan individu maupun masyarakat.

Menurut McClelland, setiap individu memiliki waktu luang, hendaknya setiap orang memanfaatkan waktu luangnya tersebut untuk berpikir mengenai bagaimana meningkatkan situasi sekarang kearah yang lebih baik, dan hendaknya melaksanakan tugas-tugas yang 
dihadapinya dengan cara yang lebih baik. Berpikir kritis merupakan salah satu cara untuk meningkatkan perubahan kearah yang lebih baik. Menurut John Dewey, secara berpikir kritis merupakan aktivitas seseorang yang memikirkan berbagai hal secara mendalam, membuat pertanyaan untuk dijawab sendiri, menemukan dan mencari informasi yang relevan untuk diri sendiri. Dia lebih mengutamakan usaha sendiri dari pada menerima hal dari orang lain (Hadi \& Junaidi, 2018)

Berdasarkan uraian permasalahan diatas, maka penelitian dengan judul: "Hubungan Kelompok Teman Sebaya terhadap Gaya Hidup Hedonisme pada Mahasiswa" perlu untuk dilakukan.

\section{Metode Penelitian}

Jenis penelitian yang digunakan adalah penelitian kuantitatif dengan desain ex-post facto, yang dikelompokkan sebagai penelitian korelatif yang bertujuan untuk mengetahui hubungan antara dua variabel atau lebih. Penelitian ini menggunakan dua variabel yaitu variabel bebas dan variabel terikat, variabel bebas merupakan variabel yang memberikan pengaruh yaitu kelompok teman sebaya, berikutnya variabel terikat merupakan variabel yang dipengaruhi yaitu gaya hidup hedonisme mahasiswa.

Populasi pada penelitian ini adalah mahasiswa S1 Fakultas Ilmu Sosial Universitas Negeri Padang tahun masuk 2016, 2017, 2018, 2019, yang terdaftar pada semester Juli sampai Desember 2019 sebanyak 4190 mahasiwa. Menghitung sampel menggunakan rumus Slovin dengan taraf kesalahan 10\% sehingga didapat jumlah sampel sebanyak 98 mahasiswa. Data pada penelitian untuk variabel kelompok teman sebaya dan gaya hidup hedonisme dikumpulkan menggunakan metode angket dengan skala Likert.

Skala kelompok teman sebaya dan skala gaya hidup hedonisme disajikan dalam pernyataan favorable dan unfavorable dengan lima alternatif jawaban yaitu Sangat Setuju (SS), Setuju (S), Kurang Setuju (KS), Tidak Setuju (TS), Sangat Tidak Setuju (STS).

Jumlah butir pernyataan yang terdapat dalam angket varibel kelompok teman sebaya sebanyak 31 butir pernyataan dan untuk variabel gaya hidup hedonisme sebanyak 32 butir pernyataan. Hasil uji validitas kuisioner untuk variabel kelompok teman sebaya diperoleh dari 31 butir pernyataan 25 butir pernyataan dinyatakan valid, untuk variabel gaya hidup hedonisme dari 32 butir pernyataan 24 butir pernyataan dinyatakan valid. Hasil uji reliabilitas untuk variabel kelompok teman sebaya memliki tingkat reliabilitas yang kuat sebesar 0,722. Untuk variabel gaya hidup hedonisme memiliki tingkat reliabilitas yang sangat kuat sebesar 0,845 , sehingga variabel kelompok teman sebaya dan variabel gaya hidup hedonisme dinyatakan reliabel.

Teknik analisis data yang digunakan dalam penelitian ini adalah analisis korelasi product moment, langkah pertama dilakukan uji normalitas, untuk mengetahui data berdistribusi normal atau tidak apabila Kp lebih besar dari alpha yang telah ditentukan yaitu 0,05 maka data berdistribusi normal, sebaliknya apabila Kp lebih kecil dari alpha maka data tidak berdistribusi normal (Priyono, 2016).

\section{Hasil dan Pembahasan}

\section{Hasil}

Hasil penelitian yang telah dilakukan pada variabel kelompok teman sebaya dan gaya hidup hedonisme untuk uji normalitas yang didapat pada penelitian ini disimpulkan pada tabel berikut: 
Tabel 1. Ringkasan Hasil Uji Normalitas

\begin{tabular}{cccc}
\hline Variabel & $\begin{array}{c}\text { Asymp. Sig. } \\
\text { value })\end{array}$ & Kondisi & Kesimpulan \\
\hline Kelompok Teman Sebaya & 0,566 & $\mathrm{p}>0,05$ & Normal \\
\hline Gaya Hidup Hedonisme & 0,377 & $\mathrm{P}>0,05$ & Normal \\
\hline
\end{tabular}

Sumber: data primer diolah 2019

Berdasarkan uji normalitas diketahui nilai signifikansi untuk variabel kelompok teman sebaya 0,566>0,05 dan variabel gaya hidup hedonisme 0,377>0,05, artinya variabel kelompok teman sebaya dan variabel gaya hidup hedonisme berdistribusi normal dan dapat dilakukan analisis data selanjutnya, karena data tersebut dapat benar-benar mewakili populasi.

Hasil uji linieritas diketahui nilai signifikansi 0,297 lebih besar dari 0,05, artinya bahwa terdapat hubungan yang linear antara variabel kelompok teman sebaya dengan variabel gaya hidup hedonisme. Berdasarkan uji hipotesis yang telah dilakukan menggunakan rumus korelasi Product Moment, diketahui bahwa kelompok teman sebaya tidak memiliki hubungan dengan gaya hidup hedonisme pada mahasiswa dengan hasil perbandingan yang diperoleh harga $r$ yaitu $r$ hitung < r tabel dimana $r$ hitung 0,1409 dan nilai $r$ tabel 0,1986.

Artinya, hipotesis $\mathrm{H} 0$ diterima dan $\mathrm{H} 1$ ditolak. koefisien determinasi r2 Square sebesar 0,01985 hal ini berarti $1,985 \%$ variabel kelompok teman sebaya mempunyai sumbangan terhadap variabel gaya hidup hedonisme pada mahasiswa, sedangkan gaya hidup pada mahasiswa lainnya dipengaruhi oleh faktor-faktor lain diluar dari kelompok teman sebaya sebesar 98,0115\% yang tidak terdapat pada penelitian ini.

Data variabel kelompok teman sebaya dan gaya hidup hedonisme diperoleh melalui angket. Hasil frekuensi statistik variabel kelompok teman sebaya diperoleh mean 88,7. Median 89, mode 89, dan standar deviasi 8,6. Nilai minimum adalah 65 dan nilai maksimum 117 dengan jumlah total 8719. Deskripsi data hipotetik diperoleh jumlah item 25 skor maksimal 125, skor minimal 25, mean 75 dan standar deviasi 16,6 sehingga diperoleh sebaran data kategorisasi untuk kategori tinggi pada skor 92-125 dengan frekuensi 35\%, kategori sedang pada skor 59-91 dengan frekuensi 64\%, dan kategori rendah 25-57 dengan frekuensi $0 \%$.

Tabel 2. Sebaran Data Kategorisasi Kelompok Teman Sebaya

\begin{tabular}{cccc}
\hline Variabel & Interval & Frekuensi & Persentase \\
\hline Tinggi & $92-125$ & 35 & $36 \%$ \\
\hline Sedang & $58-91$ & 63 & $64 \%$ \\
\hline Rendah & $25-57$ & 0 & $0 \%$ \\
\hline Jumlah & & 98 & $100 \%$ \\
\hline
\end{tabular}

Sumber: data primer diolah 2019 


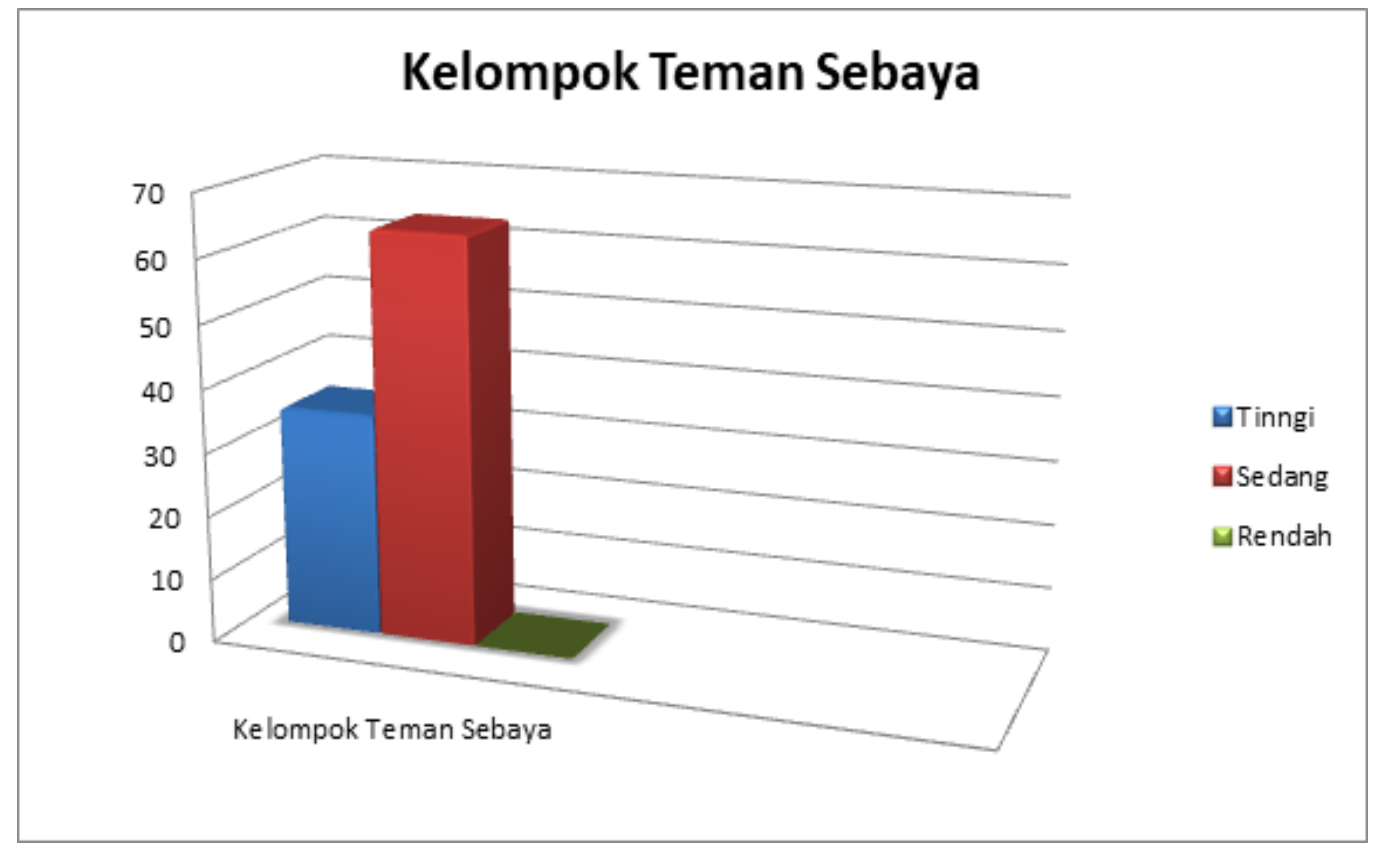

Gambar 1. Diagram Sebaran Kategorisasi Kelompok Teman Sebaya

Berdasarkan hasil analisis pada skala kelompok teman sebaya diperoleh tingkat kelompok teman sebaya pada mahasiswa S1 Fakultas Ilmu Sosial Universitas Negeri Padang tahun masuk 2016, 2017, 2018, 2019 yang terdaftar pada semester Juli sampai Desember pada kategori sedang dengan persentase 65\% yaitu sebanyak 63 mahasiswa. Dengan demikian dapat disimpulkan bahwa mahasiswa S1 Fakultas Ilmu Sosial Universitas Negeri Padang tahun masuk 2016,2017,2018,2019 memiliki kelompok teman sebaya dengan kategori sedang.

Data variabel gaya hidup hedonisme diketahui mean 58,1, median 56,5, mode 51, standar deviasi 12,6, nilai minimum 30, nilai maksimun 91 dan jumlah total 5695. Deskripsi data hipotetik diketahui jumlah item 24, skor maksimal 120, skor minimal 24, mean 72 dan standar deviasi 16. Sehingga diperoleh sebaran data kategorisasi untuk kategori tinggi pada skor 88-120 dengan frekuensi 1\%, kategori sedang pada skor 56-87 dengan frekuensi 51\%, dan kategori rendah pada skor 24-55 dengan frekuensi $48 \%$.

Tabel 3. Sebaran Data Kategorisasi Gaya Hidup Hedonisme

\begin{tabular}{cccc}
\hline Variabel & Interval & Frekuensi & Persentase \\
\hline Tinggi & $88-120$ & 1 & $1 \%$ \\
\hline Sedang & $56-87$ & 50 & $51 \%$ \\
\hline Rendah & $24-55$ & 47 & $48 \%$ \\
\hline Jumlah & & 98 & $100 \%$
\end{tabular}

Sumber: data primer diolah 2019 


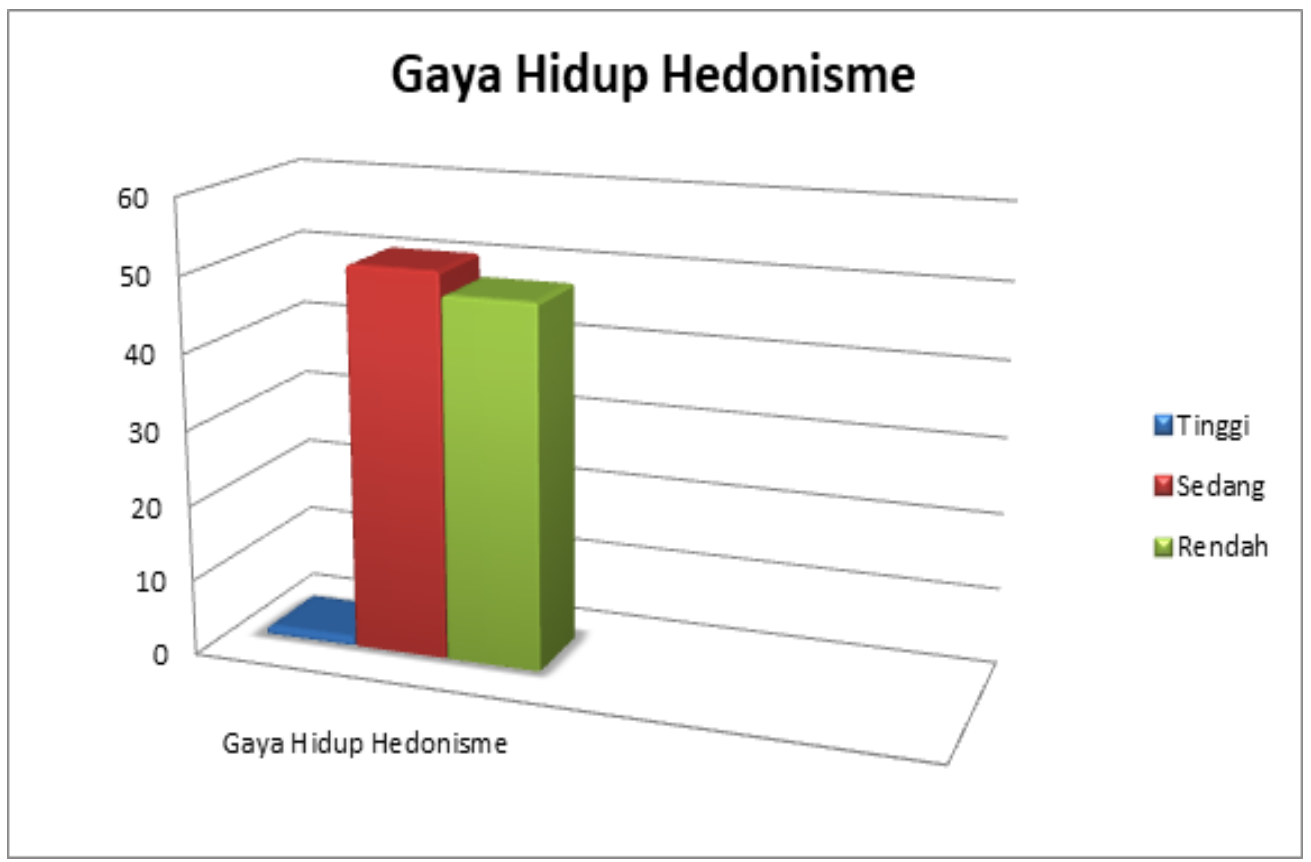

Gambar 2. Diagram Sebaran Kategorisasi Gaya Hidup Hedonisme

Dengan demikian dapat disimpulkan bahwa sebagian besar mahasiswa S1 Fakultas Ilmu Sosial Universitas Negeri Padang tahun masuk 2016, 2017, 2018, 2019 memiliki gaya hidup hedonisme dengan kategori sedang. Hasil uji korelasi indikator variabel kelomok teman sebaya yang terdiri dari kerjasama, persaingan, pertentangan, penerimaan, penyesuaian, dan perpaduan telah disimpulkan pada tabel berikut ini:

Tabel 4. Hasil Uji Korelasi

\begin{tabular}{lccc}
\hline Indikator & r hitung & R tabel & keterangan \\
\hline Kerjasama & 0,0499 & 0,1986 & Tidak Ada Korelasi \\
\hline Persaingan & 0,01167 & 0,1986 & Tidak Ada Korelasi \\
\hline Pertentangan & 0,42079 & 0,1986 & Ada Korelasi \\
\hline Penerimaan & $-0,1043$ & 0,1986 & Tidak Ada Korelasi \\
\hline Penyesuaian & 0,00418 & 0,1986 & Tidak Ada Korelasi \\
\hline Perpaduan & 0,479 & 0,1986 & Ada Korelasi \\
\hline
\end{tabular}

Sumber: data primer diolah 2019

Berdasarkan tabel diatas, diketahui dari enam indikator kelompok teman sebaya yaitu kerjasama, persaingan, pertentangan, penerimaan, penyesuaian, dan perpaduan terdapat dua indikator yang memiliki korelasi terhadap gaya hidup hedonisme. Indikator yang memiliki korelasi adalah pertentangan dengan nilai korelasi 0,42079>0,1986 dan indikator perpaduan dengan nilai korelasi 0,479>0,1986. Sedangkan indikator kerjasama, persaingan, penerimaan dan penyesuaian tidak memiliki korelasi.

\section{Pembahasan}

Penelitian ini dilakukan untuk mengetahui hubungan kelompok teman sebaya terhadap gaya hidup pada mahasiswa S1 Fakultas Ilmu Sosial Universitas Negeri Padang tahun masuk 2016, 2017, 2018, 2019 yang terdaftar pada semester Juli sampai Desember. Berdasarkan 
hasil penelitian hubungan kelompok teman sebaya terhadap gaya hidup hedonisme diperoleh hasil yang akan dibahas berikut ini:

\section{Kelompok Teman Sebaya}

Kelompok teman sebaya merupakan sekelompok individu yang memiliki usia yang sama dan status sosial yang hampir sama, kelompok teman sebaya mempunyai peranan yang cukup penting dalam penyesuaian diri individu (Susanto, 2019). Ciri-ciri kelompok teman sebaya menurut Slamet Santoso (Sihotang, 2009) adalah tidak memiliki struktur organisasi yang jelas, sifatnya sementara, kelompok teman sebaya menjarkan individu mengenai kebudayaan yang luas, dan anggota dari kelompok merupakan individu yang sebaya. Terdapat enam indikator kelompok teman sebaya yaitu kerjasama, persaingan, petentangan, penerimaan, penyesuaian, perpaduan. Indikator tersebut akan dibahas sebagai berikut:

a. Kerjasama. Indikator kerjasama dalam kelompok teman teman sebaya sangat diperlukan, hal ini disebabkan karena untuk menyatukan beberapa individu menjadi sebuah kelompok dibutuhkan adanya kerjasama. Apabila dalam sebuah kelompok terdapat kerjasama maka kelompok tersebut akan lebih mudah untuk melakukan kegiatan bersama, saling bertukar pikiran yang nantinya akan muncul ide-ide atau jalan keluar dalam menyelesaikan suatu masalah. Terdapat beberapa hal yang dapat mendukung terjalinnya kerjasama tersebut, antara lain : harus sadar dan mengakui kemampuan masing-masing, mengerti dan memahami akan masalah yang dihadapi, pihak yang bekerjasama perlu berkomunikasi, mengerti kesulitan dan kelemahan orang lain, perlu adanya pengaturan, yaitu koordinasi yang mantap, adanya keterbukaan dan kepercayaan, melibatkan orang lain. Jika kerjasama dalam kelompok teman sebaya telah terjalin dengan baik, maka kelompok teman sebaya tidak akan melakukan gaya hidup hedonisme, karena dalam kelompok teman sebaya sudah terjalin kerjasama, sehingga anggota di dalamnya tidak akan mencari kesenangan diluar dari kelompok teman sebayanya.

b. Persaingan. Persaingan dalam kelompok teman sebaya seperti memiliki rasa ingin menang dari anggota kelompok sebaya lainnya dan memiliki rasa ingin tampil beda dari kelompok teman sebaya lainnya. Artinya terdapat anggota kelompok bersaing dengan anggota kelompok lainnya untuk mencapai tujuan tanpa melakukan kekerasan fisik, dan suatu kelompok teman sebaya ingin tampil beda dengan kelompok teman sebaya lainnya. Sedangkan pada penelitian ini, kelompok teman sebaya tidak membutuhkan persaingan karena mereka lebih membutuhkan hubungan yang baik dengan kelompok teman sebayanya, memiliki motif yang tinggi untuk persahabatan, lebih menyukai situasi yang kooperatif dibandingkan kompetitif, dan menginginkan hubungan-hubungan yang melibatkan tingkat pengertian mutual yang tinggi.

c. Pertentangan. Pertentangan bisa saja terjadi dalam sebuah kelompok teman sebaya, hal ini dikarenakan tiap individu dalam sebuah kelompok teman sebaya memiliki karakter dan sifat yang berbeda. Ketika individu bertentangan dengan kelompok teman sebayanya maka individu tersebut akan mencari cara agar mendapatkan kebahagiaan diluar dari kelompok teman sebaya tersebut. Sehingga individu tersebut akan lebih mementingkan dirinya sendiri dibanding kelompok teman sebayanya. Jika individu dalam kelompok teman sebaya merasa bertentangan dengan kelompok teman sebayanya, artinya individu tersebut memiliki kontrol diri yang kuat dan hubungan dalam kelompok teman sebanya tidak baik. Menurut Goldfried dan Merbaum (Puji Astuti, 2019) bahwa kontrol diri sebagai suatu kemampuan untuk menyusun, mengatur, dan mengarahkan bentuk perilaku yang membawa individu kearah konsekuensi positif. Kontrol diri juga menggambarkan 
keputusan individu melalui pertimbangan perilaku untuk melakukan hal-hal yang diinginkannya.

d. Penerimaan. Penerimaan merupakan suatu proses sosial yang muncul ketika suatu kelompok manusia dengan kebudayaan tertentu dihadapkan dengan unsur dari suatu kebudayaan asing. Dalam sebuah kelompok menerima perbedaan tiap individu dalam suatu kelompok, serta menerima kelebihan dan kekurangan anggota kelompok teman sebaya. Kebutuhan agar dapat diterima oleh lingkungan bagi setiap individu atau remaja merupakan suatu hal yang sangat mutlak sebagai makhluk sosial. Setiap remaja yang memasuki usia remaja akan dihadapkan pada permasalahan penyesuaian sosial, yang diantaranya adalah problematika penerimaan teman sebaya (Sumiyati \& Chairunnissa, 2012).

e. Penyesuaian. Menyesuaikan diri dengan lingkungan kelompok teman sebaya dan mengikuti aturan yang telah dibuat dalam kelompok teman sebaya. Hal tersebut dilakukan agar diakui dan diterima oleh kelompok teman sebaya. Memperkuat penyesuaian moral dan nilai-nilai. Umumnya orang dewasa mengajarkan kepada anak-anak mereka tentang apa yang benar dan apa yang salah. Dalam kelompok teman sebaya, individu mencoba mengambil keputusan atas diri mereka sendiri. Individu mengevaluasi nilai-nilai yang dimilikinya dan yang dimiliki oleh teman sebayanya serta memutuskan mana yang benar. Penyesuaian diri sebagai usaha konformitas, menyiratkan bahwa disana individu seakanakan mendapat tekanan kuat untuk harus selalu mampu menghindarkan diri dari penyimpangan perilaku, baik secara moral, sosial, maupun emosional (Mukiwanti, 2019). Hal tersebut didukung oleh penelitian yang dilakukan oleh Noverani Khesari Hasil dari penelitian ini menyatakan bahwa penerimaan kelompok teman sebaya dengan konsep diri memiliki hubungan positif yang sangat signifikan antara penerimaan kelompok teman sebaya dengan konsep diri pada remaja di SMP Negeri 17 Surakarta (Khesari, 2015).

f. Perpaduan. Kepribadian anggota kelompok teman sebaya berbeda-beda, oleh karena itu dibutuhkan perpaduan tanpa membedakan antara yang satu dengan yang lainnya sehingga dapat mengikuti kebiasaan kelompok teman sebaya. Apabila terdapat salah satu anggota yang memiliki gaya hidup hedonisme maka anggota kelompok teman sebaya lainnya akan mengikuti anggota tersebut sehingga gaya hidup kelompok teman sebaya sebelumnya akan hilang dan diganti dengan gaya hidup hedonisme. Goldstein mengatakan bahwa apabila individu dihadapkan pada situasi-situasi yang dapat dikuasainya, maka ia akan berkembang secara normal melalui pematangan dan latihan, apabila masalah baru timbul, maka ia akan membentuk pola-pola baru untuk menanggulanginya. Reaksi-reaksi yang tidak berguna lagi untuk tujuan aktualisasi diri akan ditinggalkan (Iskandar, 2016).

\section{Gaya Hidup Hedonisme}

Gaya hidup hedonisme menurut Levan's dan Linda dalam (Patricia \& Handayani, 2007) gaya hidup hedonisme merupakan pola perilaku yang bisa diketahui dari aktivitas, minat dan opini yang selalu menekankan pada kesenangan hidup. Terdapat dua faktor yang mempengaruhi gaya hidup sesorang yaitu faktor eksternal dan faktot internal. Faktor eksternal yang dapat menjadi faktor pengaruh gaya hidup adalah sikap, pengalaman, pengamatan, kepribadian, konsep diri, dan motif. Kemudian faktor internal yang mempengaruhi gaya hidup adalah kelompok referensi, keluarga, kelas sosial, dan kebudayaan. Hasil penelitian yang telah dilakukan menunjukkan bahwa mahasiswa S1 Fakultas Ilmu Sosial Universitas Negeri Padang tahun masuk 2016, 2017, 2018, 2019 dengan kategori sedang. Hal tersebut menunjukkan bahwa kebanyakan mahasiswa S1 Fakultas Ilmu 
Sosial, Universitas Negeri Padang memiliki suatu pola hidup khas baik itu dari sikap, cara, dan pola tindakan untuk menggapai tujuan tertentu, konsep diri dan perasaan. Konsep diri dan perasaan mengarah pada tujuan untuk mendapatkan kepuasan yang dilakukan dalam bentuk aktivitas minat dan pendapat dengan melakukan segala cara. Berdasarkan penelitian yang dilakukan oleh Viska Lukitasari yang menunjukkan profil gaya hidup hedonisme dikalangan mahasiswa FBS UNESA antara lain meliputi perilaku konsumtif yaitu berbelanja dan mengoleksi barang-barang bermerek, menghabiskan waktu luang untuk mengunjungi tempat nongkrong, dan aktivitas berlibur yang terlalu sering. Penelitian lain dilakukan oleh Rianton (2013) hasil penelitian menunjukkan bahwa kategori tingkat konformitas kebanyakan mahasiswa Dhamasraya (JIMDY) adalah dengan tingkat sedang sebesar 81,8\%, sedangkan kategori tingkat gaya hidup hedonisme pada mahasiswa Dhamasraya (JIMDY) adalah sebesar $94,5 \%$. Hasil penelitian lain adalah penelitian yang telah dilakukan oleh Sholikhah dan Dhania (2017) yang menunjukkan besarnya pengaruh gaya hidup hedonis serta konformitas teman sebaya dengan perilaku impulsive sebesar $37,1 \%$ dan sisanya dipengaruhi faktor lain (Danti, 2016)

\section{Hubungan Kelompok Teman Sebaya Terhadap Gaya Hidup Hedonisme pada Mahasiswa}

Hasil penelitian menunjukkan bahwa kelompok teman sebaya tidak mempengaruhi gaya hidup hedonisme karena mahasiswa memilki kontrol diri, pendirian serta jati diri yang kuat sehingga mahasiswa tidak akan mudah terpengaruh oleh kelompok teman sebayanya. Hal tersebut sama hal nya dengan penelitian yang telah dilakukan oleh Fatimah (2013) hasil penelitian menunjukkan bahwa semakin tinggi kontrol diri seseorang maka akan semakin rendah gaya hidup hedonismenya dan semakin rendah kontrol diri seseorang maka akan semakin tinggi gaya hidup hedonismenya.

Hal ini berarti gaya hidup hedonisme tidak dipengaruhi oleh adanya kelompok teman sebaya. Faktor lain yang mempengaruhi gaya hidup hedonisme menurut Praja dan Damayantie (Fitriyani, 2016) yaitu teman sebaya, lingkungan dan kontrol diri. Teman sebaya dalam hal ini adalah teman yang memiliki gaya hidup hura-hura dan terkesan bermewahmewahan, lingkungan sendiri adalah lingkungan yang tidak memiliki kepekaan terhadap perilaku menyimpang yang terjadi sehingga lingkungan cenderung membiarkan, kurangnya kontrol dari orang tua yang memberikan kebebasan sepenuhnya terhadap anaknya sehingga individu juga menjadi tidak dapat mengontrol dirinya dari pengaruh kelompok. Hal ini menujukkan bahwa hedonisme dipengaruhi oleh faktor lain seperti lingkungan.

Hedonisme merupakan suatu gaya hidup yang akan berdampak kepada pola kehidupan dari setiap manusia yang melakukannya termasuk mahasiswa. Hedonisme merupakan sebuah bentuk penyimpangan perilaku dari seseorang yang tidak seharusnya dilakukan orang tersebut dan dapat menimbulkan masalah yang cukup serius terhadap generasi muda khususnya mahasiswa sebagai calon penerus bangsa Indonesia. Dampak selalu muncul sebagai akibat dari setiap perbuatan yang dilakukan mahasiswa termasuk gaya hidup yang hedonis. Adapun yang menjadi dampak dari gaya hidup hedonisme sepenuhnya berupa halhal yang bersifat negatif. Hal ini dikarenakan tujuan pendidikan negara kita adalah untuk mencerdaskan kehidupan bangsa.

Tujuannya tentu bukan untuk menciptakan bangsa yang hedonisme, tetapi bangsa yang punya spiritual, punya emosional quotient atau peduli pada sesama dan tidak selfish atau mengutamakan diri sendiri. Gaya hidup hedonisme sama sekali tidak sesuai dengan tujuan pendidikan bangsa kita. Salah satu dampak yang berpengaruh pada mahasiswa yakni cara mereka menjalani hidup, menghabiskan waktu, apa yang mereka anggap penting dalam lingkungannya, dan apa yang mereka pikirkan tentang diri mereka sendiri dan juga dunia di 
sekitarnya. Mahasiswa yang memiliki gaya hidup hedonisme tidak memanfaatkan waktu luang yang dimiliki untuk melakuan kegiatan atau aktivitas yang dapat membawa perubahan kearah yang lebih. Banyak waktu, tenaga dan pikirian yang dikerahkan demi mencapai kesenangan hidup. sehingga waktu, tenaga dan fikiran yang seharusnya digunakan untuk dunia perkuliahan menjadi lebih sedikit.

Berdasarkan Teori kebutuhan McClelland (McClelland's Theory of needs) dikembangkan oleh David McClelland dan rekan-rekannya. Teori ini berfokus pada tiga kebutuhan yaitu kebutuhan pencapaian (need for achievement), kebutuhan kekuasaan (need for power), dan kebutuhan hubungan (need for affiliaton) (El Adawiyah, 2019). Teori McClelland yang biasa dikenal teori n-Ach (need for achievement) dalam (Nanang, 2011) yang menjelaskan kebutuhan untuk berprestasi dalam mendukung kemajuan individu masyarakat. Menurut McClelland setiap individu memiliki waktu luang, seharusnya waktu luang yang dimiliki individu tersebut digunakan untuk berpikir tentang bagaimana cara meningkatkan situasi saat ini kearah yang lebih baik, dan sebaiknya melaksanakan tugastugas yang dihadapi individu tersebut dengan cara yang lebih baik.

Kebutuhan kekuatan atau nPow merupakan keinginan untuk memiliki pengaruh, menjadi yang berpengaruh, dan mengendalikan individu lain. Dalam bahasa sederhana, ini adalah kebutuhan atas kekuasaan dan otonomi. Individu dengan nPow tinggi, lebih suka bertanggung jawab, berjuang untuk mempengaruhi individu lain, senang ditempatkan dalam situasi kompetitif, dan berorientasi pada status, dan lebih cenderung lebih khawatir dengan wibawa dan pengaruh yang didapatkan ketimbang kinerja yang efektif. Kelompok tempat sebaya dapat memberi pengaruh terhadap angggota nya, namun pada penelitian kategori kelompok teman sebaya berada pada tingkat sedang, artinya kelompok teman sebaya tidak memiliki pengaruh yang kuat terhadap individu lain, karena individu tersebut memiliki pertahanan diri dan komitmen yang kuat. Mahasiswa yang memiliki gaya hidup hedonisme tidak melakukan pekerjaan atau kegiatan yang dilakukannya secara efektif.

Kebutuhan lain yaitu nAff adalah kebutuhan untuk memperoleh hubungan sosial yang baik dalam lingkungan. Kebutuhan ini ditandai dengan memiliki motif yang tinggi untuk persahabatan, lebih menyukai situasi kooperatif dibandingkan kompetitif, dan menginginkan hubungan-hubungan yang melibatkan tingkat pengertian mutual yang tinggi. McClelland mengatakan bahwa kebanyakan orang memiliki dan menunjukkan kombinasi tiga karakteristik tersebut, dan perbedaan ini juga mempengaruhi bagaimana gaya seseorang berperilaku (El Adawiyah, 2019).

Menurut Siswanto (Priyanto \& Edy Mulyono, 2017) Manusia sebagai makhluk monodualis terdiri dari dua unsur yaitu jasmani dan rohani yang merupakan kesatuan yang utuh. Pertumbuhan, perkembangan kehidupan manusia mempunyai kebutuhan, Kebutuhankebutuhan itu untuk dapat diperhatikan dalam upaya mencapai kesejahteraan dan kebahagiaan hidup. Mahasiswa membutuhkan sebuah kelompok teman sebaya untuk memperoleh hubungan sosial yang baik dalam lingkungan sekitarnya. Kelompok teman sebaya dapat memberikan motivasi dan dukungan terhadap anggota dalam kelompok tersebut, jika salah satu anggota memiliki masalah maka anggota kelompok lainnya akan ikut membantu menyelesaikan masalah tersebut.

Hasil yang diperoleh pada penelitian ini menunjukkan hasil bahwa kelompok variabel kelompok teman sebaya memiliki tingkat kategori sedang dan variabel gaya hidup hedonisme memiliki tingkat kategori sedang, artinya kekuatan kelompok teman sebaya pada mahasiswa S1 Fakultas Ilmu Sosial Universitas Negeri Padang untuk mepengaruhi anggota kelompok teman sebaya lainnya hanya pada kategori sedang dan memiliki kontrol diri yang tinggi 
terhadap perilaku atau gaya hidup, sehingga anggotanya tidak akan mudah terpengaruh untuk melakukan tindakan di luar dari kontrol dirinya. Hal ini didukung oleh penelitian yang telah dilakukan oleh Nabila Nur Fitriyani (2016) hasil penelitian diperoleh tidak terdapat hubungan antara konformitas dengan gaya hidup hedonisme yang menunjukkan bahwa dalam penelitian ini mayoritas siswa tidak bersifat konformitas karena para siswa masih bisa mengontrol dirinya sehingga tidak terpengaruh oleh pergaulan kelompok disekolah. Selain itu individu juga memiliki pendirian yang kuat sehingga tidak mudah terpengaruh oleh teman-temanya, sehingga individu mampu menjadi diri sendiri yang mandiri dan memiliki pemikiran yang berbeda dengan temanya yang lain. Subjek penelitian sudah mulai bisa menentukan identitas diri sehingga mereka ingin menunjukkan jati diri mereka dengan menjadi diri sendiri tanpa meniru dan mengikuti pengaruh dari teman-teman sebayanya. Kemampuan mengontrol diri memungkinkan seseorang berperilaku lebih terarah dan dapat menyalurkan dorongandorongan dalam diri secara benar dan tidak menyimpang dari norma masyarakat (Faried \& Nashori, 2012).

Sedangkan untuk gaya hidup hedonisme pada mahasiswa S1 Fakultas Ilmu Sosial Universitas Negeri Padang berada pada tingkat kategori sedang, artinya mahahiswa memiliki kebutuhan pencapaian yang tinggi baik itu dari segi akademik maupun organisasi, lebih menyukai situasi-situasi pekerjaan yang memiliki tanggung jawab pribadi, umpan balik, dan risiko tingkat menengah. Individu yang cenderung berorientasi pada gaya hidup hedonis belum memiliki kontrol diri yang baik. Individu yang memiliki kontrol diri yang tidak baik memiliki karakteristik sebagai berikut individu tersebut kurang dapat mengontrol pengeluaran uang, suka melakukan pemborosan uang, kurang dapat mengendalikan pikiran yang membuatnya justru tertekan, pikirannya sering kacau karena suatu permasalahan, tidak memiliki pilihan (Fatimah, 2013). Kebutuhan yang tinggi untuk pencapaian tidak selalu membuat individu menjadi lebih baik (p. Robibns \& A. Judge, 2008), kelompok teman sebaya yang baik tertarik dengan seberapa baik mereka bekerja secara pribadi dan tidak dengan memengaruhi individu lain untuk bekerja dengan baik. Oleh sebab tidak terdapat hubungan kelompok teman sebaya terhadap gaya hidup hedonisme pada mahasiswa.

\section{Kesimpulan}

Berdasarkan penelitian yang telah dilakukan dapat diambil kesimpulan bahwa tidak tedapat hubungan antara kelompok teman sebaya terhadap gaya hidup hedonisme pada mahasiswa S1 Fakultas Ilmu Sosial Universitas Negeri Padang tahun masuk 2016, 2017, 2018, 2019 yang terdaftar pada semester Juli sampai Desember 2019 yang dapat dilihat dari hasil uji hipotesis dengan rumus korelasi product-moment diperoleh hasil perbandingan $\mathrm{r}$ hitung lebih kecil dari $r$ tabel dengan nilai $r$ hitung 0,1409 > $r$ tabel 0,1986 sehingga hipotesis $\mathrm{H}_{0}$ diterima dan hipotesis $\mathrm{H}_{1}$ ditolak. Dari olahan data koofisien determinasi didapat $\mathrm{r}^{2}$ Square sebesar 0,01985 hal ini berarti $1,985 \%$ variabel kelompok teman sebaya mempunyai sumbangan terhadap variabel gaya hidup hedonisme pada mahasiswa, sedangkan gaya hidup pada mahasiswa lainnya dipengaruhi oleh faktor-faktor lain diluar kelompok teman sebaya sebesar 98,015\% yang tidak diteliti dalam penelitian ini. Berdasarkan kesimpulan diatas terdapat beberapa saran, diharapkan pada mahasiswa agar lebih dapat memperhatikan hubungan dalam kelompok teman sebaya. Selain itu mahasiswa sebaiknya memanfaatkan waktu luang yang dimiliki untuk melakukan aktivitas yang bermanfaat yang dapat menciptakan perubahan kearah yang lebih baik, dan menjalankan tugas sebagai seorang mahasiswa dengan lebih baik lagi. Diharapkan kepada penelitian selanjutnya agar lebih cermat dalam pemilihan pendekatan dan metode yang digunakan karena teknologi kini 
semakin berkembang dari waktu ke waktu. Penulis juga menyarankan untuk meneliti faktor lain yang juga mempengaruhi gaya hidup hedonisme.

\section{Daftar Pustaka}

Danti, I. A. (2016). Pengaruh Pergaulan Kelompok Teman Sebaya dan Motivasi Belajar Terhadap Prestasi Belajar Akuntansi Siswa Kelas XI IPS SMA N 1 Parakan Tahun Ajaran 2015/2016. Universitas Negeri Yogyakarta.

El Adawiyah, S. (2019). Buku Ajar Human Relations (Retnowati, Ed.). Diambil dari https://books.google.co.id/books?id=yX6MDwAAQBAJ\&printsec=frontcover\&hl=id\# $\mathrm{v}=$ onepage $\& \mathrm{q} \& \mathrm{f}=$ false

Erliana, P. (2018). Pengaruh Gaya Hidup Hedonisme Terhadap Kecurangan Akademik Mahasiswa Bimbingan dan Konseling.

Faried, L., \& Nashori, F. (2012). Hubungan Antara Kontrol Diri Dan Kecemasan Menghadapi Masa Pembebasan Pada Narapidana Di Lembaga Pemasyarakatan Wirogunan Yogyakarta. 5(2), 63-74.

Fatimah, S. (2013). Hubungan Antara Kontrol Diri Dengan Kecenderungan Gaya Hidup Hedonis pada Mahasiswi di Surakarta.

Fernandes, R., Putra, E. V., \& Muspita, R. (2013). Optimalisasi Institusi Pendidikan Sebagai Upaya. ABDI : Jurnal Pengabdian dan Pemberdayaan Masyarakat, 1(April 2019), 1620.

Fitriyani, N. (2016). Hubungan antara Konformitas dengan Gaya Hidup Hedonisme.

Hadi, D. I., \& Junaidi, J. (2018). Upaya Meningkatkan Kemampuan Berpikir Kritis Melalui Penerapan Model Pembelajaran Berbasis Masalah Pada Pembelajaran Sosiologi Kelas Xi IPS 2 SMA Negeri 1 Pariaman. Socius, 4(1), 22. https://doi.org/10.24036/scs.v4i1.14

Irfan, \& Sylvia, I. (2012). Hubungan Antara Konformitas Kelompok Teman Sebaya dengan Disiplin Siswa SMA N 5 Padang. XII(83), 205-213. https://doi.org/10.31227/osf.io/tm5ba

Iskandar. (2016). Implementasi teori hirarki kebutuhan abraham maslow terhadap peningkatan kinerja pustakawan. Jurnal Ilmu Perpustakaan, Informasi, dan Kearsipan Khizanah Al- Hikmah, 4(1), 24-34.

Khesari, N. (2015). Hubungan Antara Penerimaan Kelompok Teman Sebaya Dengan Konsep Diri Pada Remaja. 16(2), 39-55. https://doi.org/10.1377/hlthaff.2013.0625

Mardiani Amelia. (2007). Hubungan Antara Konformitas Terhadap Teman Sebaya Dengan Kecenderungan Gaya Hidup Experiencers Pada Siswa Kelas Xi Sma Labschool Jakarta. 1-39.

Mukiwanti, M. J. (2019). Kedisiplinan Shalat Siswa Kelas X Jurusan Teknik Permesinan Di Smk N 1 Semarang. Universitas Islam Negeri Walisongo Semarang.

Nanang, M. (2011). Sosiologi Perubahan Sosial: Perspektif Klasik, Modern, Posmodern, dan Poskolonial. Jakarta: Rajawali Pers.

Nur Ambadra, D. (2018). Gaya Hidup Hedonis pada Mahasiswa.

p. Robibns, S., \& A. Judge, T. (2008). Perilaku Organisasi (12 ed.; D. Angelica, R. Cahyani, \& A. Rosyid, Ed.). Diambil dari https://books.google.co.id/books?id=IwrWupB1rC4C\&pg=PA230\&dq=teori+david+m cclelland\&hl=id\&sa $=$ X\&ved=0ahUKEwi-_Z-L6pLnAhUNSX0KHXT

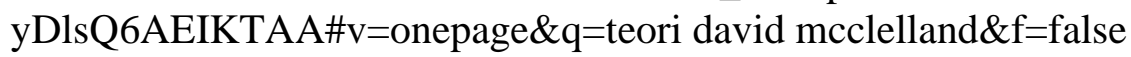

Patricia, N. L., \& Handayani, S. (2007). Pengaruh Gaya Hidup Hedonis Terhadap Perilaku Konsumtif Pada Pramugari Maskapai Penerbangan " $X$.” 
Priyanto, B., \& Edy Mulyono, S. (2017). Interaksi Sosial Anak Jalanan Dengan Teman Sebaya Di Yayasan Setara Kota Semarang . ( Social Interaction With Street Children Peers In Yayasan Setara In Semarang ) Bagus Priyanto , Sungkowo Edy Mulyono Fakultas Ilmu Pendidikan Universitas Negeri Semarang. 2(2), 164-172.

Priyono. (2016). Metode Penelitian Kuantitatif. Sidoarjo: Zifatama Publishing.

Puji Astuti, M. (2019). Tingkat Kontrol Diri Remaja Terhadap Perilaku Negatif (Studi Deskriptif Pada Siswa Kelas Viii Smp Santo Aloysius Turi Tahun Ajaran 2018/2019). Universitas Sanata Dharma Yogyakarta.

Rianton. (n.d.). Hubungan Antara Konformitas Kelompok Teman Sebaya Dengan Gaya Hidup Hedonis Pada Mahasiwa Kab. Dhamasraya di Yogyakarta.

Sa'adah, I. N. (2016). Pengaruh Gaya Hidup Dan Kepribadian Terhadap Keputusan Pembelian Jilbab Rabbani (Studi Kasus Pada Remaja Putri Di Desa Undaan Lor Undaan Kudus). 10-34.

Saputri, A., \& Rachmatan, R. (2009). Religiusitas Dengan Gaya Hidup Hedonisme : Sebuah Gambaran Pada Mahasiswa Universitas Syiah Kuala Religiosity and Hedonistic Lifestyle : An Overview at Syiah Kuala University ( Unsyiah ) Student. Psikologi.

Sihotang, A. (2009). Hubungan Antara Konformitas terhadap Kelompok Teman Sebaya Dengan Pembelian Impulsif pada Remaja.

Sumiyati, A., \& Chairunnissa. (2012). Hubungan Antara Penerimaan Kelompok Teman Sebaya dengan Prestasi Akademik Mahasiswa Pada Fakultas Ekonomi Universitas Negeri Jakarta. Jurnal Ekonomi dan Pendidikan, 7(2), 105-118. https://doi.org/10.21831/jep.v7i2.568

Susanto, I. (2019). Pengaruh Kelompok Teman Sebaya terhadap Perilaku Menyimpang Peserta Didik di Sekolah. 53(9). https://doi.org/10.1017/CBO9781107415324.004 